\title{
Expert System for Diagnosing Human Skin Diseases Using Web-Based Naïve Bayes Method
}

\section{Sistem Pakar Diagnosis Penyakit Kulit Manusia Menggunakan Metode Naïve Bayes Berbasis Web}

\author{
Khoirunnisa Devita Sari ${ }^{1}$, Ade Eviyanti ${ }^{2}$ \\ \{171080200151@umsida.ac.id ${ }^{1}$, adeeviyanti@umsida.ac.id² $\}$
}

Universitas Muhammadiyah Sidoarjo, Indonesia ${ }^{1}$, Universitas Muhammadiyah Sidoarjo, Indonesia ${ }^{2}$

\begin{abstract}
Skin disease is a disease that often found in tropical countries like Indonesia. According to the survey, skin disease is the third of the ten most outpatient diseases. Lack of public knowledge about skin diseases and how to prevent and treat them can cause a person to develop acute skin diseases. The purpose of this research is to create an expert system application for diagnosis of human skin diseases using the web-based naïve Bayes method. With expert system, it hoped that human skin diseases can be detected early and can minimize the occurrence of more dangerous diseases. The calculation in this expert system uses the naïve Bayes method. This expert system makes diagnosis by analyzing input of symptoms experienced by patient and then processing it using certain rules according the expert knowledge that has been stored in the knowledge base. The result of this research is to build an expert system for diagnosing human skin diseases using website-based naïve Bayes. The results of the system trial of 20 respondents were the website could provide diagnosis results based on the inputted rules and could diagnose skin diseases properly. This website can used as an alternative use of technology so it can be used to diagnose skin diseases quickly, precisely and accurately. So in the future the handling of skin diseases can be faster and more efficient.
\end{abstract}

Keywords - exspert system; human skin disease; naïve bayes

Abstrak. Penyakit kulit adalah penyakit yang sering ditemukan di negara tropis seperti Indonesia. Menurut survey, penyakit kulit menduduki peringkat ketiga dari sepuluh penyakit terbanyak pasien rawat jalan. Kurangnya pengetahuan masyarakat tentang penyakit kulit serta cara pencegahan dan pengobatannya dapat mengakibatkan seseorang terkena penyakit kulit tingkat akut. Tujuan dari penelitian ini adalah agar terciptanya sebuah aplikasi sistem pakar diagnosis penyakit kulit manusia menggunakan metode nä̈ve bayes berbasis web. Dengan adanya sistem pakar ini diharapkan penyakit kulit pada manusia dapat dideteksi sejak dini dan dapat meminimalkan terjadinya penyakit yang lebih berbahaya. Perhitungan dalam sistem pakar ini menggunakan metode nä̈ve bayes. Sistem pakar ini melakukan diagnosis dengan cara menganalisis masukan gejala yang dialami oleh pasien lalu diolah dengan menggunakan aturan tertentu sesuai dengan pengetahuan pakar yang sudah disimpan dalam basis pengetahuan. Hasil dari penelitian ini adalah membangun sistem pakar diagnosis penyakit kulit manusia menggunakan naïve bayes berbasis website. Hasil uji coba sistem terhadap 20 responden adalah website dapat memberikan hasil diagnosis berdasarkan aturan yang telah diinputkan dan dapat mendiagnosis penyakit kulit dengan baik. Website ini dapat dijadikan alternatif pemanfaatan teknologi agar dapat digunakan untuk mendiagnosis penyakit kulit secara cepat, tepat dan akurat. Sehingga kedepannya penanganan penyakit kulit bisa lebih cepat dan lebih efisien.

Kata Kunci - sistem pakar; penyakit kulit; nä̈ve bayes

\section{Pendahuluan}

Kulit adalah organ yang sangat penting lantaran fungsi kulit adalah untuk melindungi organ dalam tubuh dari lingkungan luar seperti bakteri bakteri dan virus. Kulit juga berfungsi untuk mengatur suhu pada badan manusia dan menjadi salah satu indra yang dimiliki manusia yaitu indra peraba.

Di banyak negara yang beriklim tropis yang setiap tahun pasti melalui musim hujan dan kemarau, terutama pada negara negara yang masih tergolong berkembang, penyakit kulit pada manusia sangat banyak ditemukan. Tak terkecuali pada negara Indonesia, cuaca atau suhu yang terkadang panas dan kering atau terkadang kelembapan yang tinggi dapat membuat kulit rentan terserang berbagai macam penyakit, termasuk penyakit kulit.

Berdasarkan Data Profil Kesehatan Indonesia pada tahun 2015, penyakit kulit pada manusia menduduki peringkat ketiga dari sepuluh penyakit terbanyak pasien rawat jalan dirumah sakit se-Indonesia. Kasus penyakit kulit di Indonesia masih tergolong sangat tinggi dan menjadi permasalahan yang berarti. Hal tersebut bisa terjadi karena kurangnya kesadaran dan ketidak pedulian masyarakat terhadap lingkungan hidup yang menyebabkan penularan penyakit kulit menjadi cepat ${ }^{[1]}$.

Penyakit kulit diketahui memiliki dampak yang signifikan terhadap kualitas hidup, produktivitas dan kesehatan mental pada manusia. Dalam menetapkan prioritas kesehatan kebanyakan manusia saat ini sangat mengganggap remeh 
Procedia of Engineering and Life Science Vol. 1. No. 2 Juni 2021

Seminar Nasional \& Call Paper Fakultas Sains dan Teknologi (SENASAINS 2nd) Universitas Muhammadiyah Sidoarjo

pada penyakit kulit. Mereka menganggap menderita penyakit kulit tidak berbahaya karena tidak menyebabkan kematian seperti HIV / AIDS, pneumonia, dan tuberkulosis. Hal tersebut sangatlah salah karena jika seseorang menderita penyakit kulit yang dibiarkan terus menerus akibatnya akan sangat fatal. Penyakit kulit akan terus menyebar dan sangat sulit diobati hingga sampai menyebabkan kematian.

Kurangnya pengetahuan masyarakat awam tentang penyakit kulit serta cara pencegaha dan pengobatannya dapat mengakibatkan seseorang terkena penyakit kulit tingkat akut. Dengan bantuan teknologi komputer saya berharap penyakit yang mempengaruhi kulit tubuh manusia dapat dideteksi sejak dini dan dapat meminimalkan terjadinya penyakit yang lebih berbahaya. Berkat hadirnya teknologi komputer untuk diagnosis penyakit kulit banyak manfaat yang bisa didapat yaitu meningkatkan efisiensi kerja, serta menghemat waktu untuk memecahkan masalah.

Penelitian yang berjudul "SISTEM PAKAR DIAGNOSIS PENYAKIT KULIT MANUSIA MENGGUNAKAN METODE NAÏVE BAYES BERBASIS WEB” yang dihasilkan bertujuan untuk mengetahui penyakit kulit seseorang tanpa harus menemui dokter yang dapat diakses melalui website. Serta diharapkan hasil penelitian ini berupa klasifikasi penyakit kulit pada manusia dapat membantu dalam mempermudah pekerjaan pihak dokter ataupun konsultasi pada pasien dengan harapan dapat memberikan informasi kepada setiap pengguna untuk memperkecil terjadinya penyakit kulit yang lebih berbahaya.

\section{METODE}

\section{A. Objek Penelitian}

Objek pada penelitian ini hanyalah tertuju pada penyakit kulit dengan gejala gatal gatal yang sering terjadi pada pasien penderita penyakit kulit. Terdapat 10 jenis penyakit kulit dengan gejala gatal yang diangkat pada penelitian ini yaitu Dermatitis Atopik, Urtikaria, Dermatitis Kontak (Alergi), Steven Johnsons Syndrome, Tinea, Kandidiasis, Impetigo, Herpes Zoster, Veruka, Psoriasis. Metode pengumpulan data dengan menggunakan teknik observasi, wawancara serta sekunder, yakni teknik pengumpulan data yang bisa didapatkan melalui buku Penyakit Kulit Yang Umum Di Indonesia oleh Emmy S. Sjamsoe Daili, Sri Linuwih Menaldi, I Made Wisnu Penerbit PT Medical Multimedia Indonesia ${ }^{[2]}$.

\section{B. Basis Pengetahuan}

Sistem pakar adalah kecerdasan buatan yang mengadopsi fakta fakta, pengetahuan dan teknik penalaran pakar yang berguna untuk memecahkan permasalahan yang hanya dapat dipecahkan oleh pakar dalam bidang tersebut ${ }^{[3]}$. Basis pengetahuan adalah inti dari sebuah sistem pakar, berupa representasi pengetahuan dari seorang pakar dan pengetahuan non-formal. Biasanya bersumber dari buku, jurnal atau artikel. Basis pengetahuan tersusun atas fakta yang berupa informasi tentang cara untuk membangkitkan suatu fakta baru dari fakta yang telah ada ${ }^{[4]}$. Jenis jenis penyakit, gejala gejala dari penyakit kulit yang, hubungan antara jenis penyakit dengan gejala gejala penyakit dan bobot pada gejala penyakit akan disajikan pada tabel dibawah :

Tabel 1. Tabel keterangan jenis penyakit

\begin{tabular}{|l|l|}
\hline Kode Penyakit & \multicolumn{1}{|c|}{ Jenis Penyakit } \\
\hline P1 & Dermatitis Atopik \\
\hline P2 & Urtikaria \\
\hline P3 & Dermatitis Kontak (Alergi) \\
\hline P4 & Steven Johnsons Syndrome \\
\hline P5 & Tinea \\
\hline P6 & Kandidiasis \\
\hline P7 & Impetigo \\
\hline P8 & Herpes Zoster \\
\hline P9 & Veruka \\
\hline P10 & Psoriasis \\
\hline
\end{tabular}

Tabel 2. Tabel keterangan gejala penyakit

\begin{tabular}{|l|l|}
\hline Kode Gejala & \multicolumn{1}{|c|}{ Gejala } \\
\hline G1 & Kulit terasa gatal \\
\hline G2 & Kulit terasa nyeri \\
\hline G3 & Kulit pecah-pecah, terkelupas \\
\hline G4 & Kulit terasa panas atau terbakar \\
\hline
\end{tabular}


Procedia of Engineering and Life Science Vol. 1. No. 2 Juni 2021

Seminar Nasional \& Call Paper Fakultas Sains dan Teknologi (SENASAINS 2nd)

Universitas Muhammadiyah Sidoarjo

\begin{tabular}{|l|l|}
\hline G5 & Kulit terdapat bercak atau ruam merah \\
\hline G6 & Kulit kering dan bersisik \\
\hline G7 & Kulit terdapat ruam yang menonjol dan mengeluarkan cairan. \\
\hline G8 & Kulit menebal atau mengetat \\
\hline G9 & Memiliki alergen makanan atau alergen hirup (debu, serbuk sari, dll) \\
\hline G10 & Kulit terdapat bercak putih \\
\hline G11 & Kulit terdapat bercak hitam atau kecoklatan \\
\hline G12 & Terdapat maserasi pada kulit \\
\hline G13 & Kulit terasa seperti tersengat, tertusuk atau kesemutan \\
\hline G14 & Kulit bintik bintik kecil disertai bengkak \\
\hline G15 & Memiliki alergen pada obat obatan \\
\hline G16 & Kulit melepuh \\
\hline G17 & Kulit disekitar luka mengalami iritasi \\
\hline G18 & Kulit terdapat tonjolan merah atau coklat dan kasar \\
\hline G19 & Kulit terdapat tonjolan berupa papul \\
\hline G20 & Kulit timbul koreng kekuningan \\
\hline
\end{tabular}

Tabel 3. Tabel hubungan antara jenis penyakit dengan gejala penyakit

\begin{tabular}{|c|l|l|}
\hline No. & \multicolumn{1}{|c|}{ Jenis Penyakit } & \multicolumn{1}{c|}{ Gejala } \\
\hline 1 & Dermatitis Atopik & G1, G3, G5, G6, G7, G8, G9, G14 \\
\hline 2 & Urtikaria & G1, G5, G8, G9, G10, G13, G14, G15 \\
\hline 3 & Dermatitis Kontak (Alergi) & G1, G2, G3, G4, G5, G7, G9, G14, G16 \\
\hline 4 & Steven Johnsons Syndrome & $\mathrm{G} 1, \mathrm{G} 2, \mathrm{G} 3, \mathrm{G} 5, \mathrm{G} 6, \mathrm{G} 10, \mathrm{G} 11, \mathrm{G} 12, \mathrm{G} 16, \mathrm{G} 18, \mathrm{G} 19$ \\
\hline 5 & Tinea & $\mathrm{G} 1, \mathrm{G} 3, \mathrm{G} 5, \mathrm{G} 6, \mathrm{G} 10, \mathrm{G} 11, \mathrm{G} 12, \mathrm{G} 16$ \\
\hline 6 & Kandidiasis & $\mathrm{G} 1, \mathrm{G} 2, \mathrm{G} 3, \mathrm{G} 4, \mathrm{G} 5, \mathrm{G} 6, \mathrm{G} 10, \mathrm{G} 12, \mathrm{G} 19$ \\
\hline 7 & Impetigo & $\mathrm{G} 1, \mathrm{G} 2, \mathrm{G} 5, \mathrm{G} 7, \mathrm{G} 16, \mathrm{G} 17, \mathrm{G} 20$ \\
\hline 8 & Herpes Zoster & $\mathrm{G} 1, \mathrm{G} 2, \mathrm{G} 4, \mathrm{G} 5, \mathrm{G} 13, \mathrm{G} 16, \mathrm{G} 19$ \\
\hline 9 & Veruka & $\mathrm{G} 1, \mathrm{G} 2, \mathrm{G} 18, \mathrm{G} 19$ \\
\hline 10 & Psoriasis & $\mathrm{G} 1, \mathrm{G} 4, \mathrm{G} 5, \mathrm{G} 6, \mathrm{G} 8, \mathrm{G} 16, \mathrm{G} 19$ \\
\hline
\end{tabular}

Tabel 4. tabel bobot pada gejala penyakit

\begin{tabular}{|c|c|c|c|c|c|c|c|c|c|c|c|c|c|c|c|c|c|c|c|c|}
\hline $\mathrm{G}$ & 1 & 2 & 3 & 4 & 5 & 6 & 7 & 8 & 9 & 10 & 11 & 12 & 13 & 14 & 15 & 16 & 17 & 18 & 19 & 20 \\
\hline 1 & 0,4 & & 0,3 & & 0,3 & 0,1 & 0,3 & 0,2 & 0,2 & & & & & 0,3 & & & & & & \\
\hline 2 & 0,4 & & & & 0,2 & & & 0,3 & 0,3 & 0,2 & & & 0,4 & 0,2 & 0,3 & & & & & \\
\hline 3 & 0,4 & 0,3 & 0,3 & 0,3 & 0,3 & & 0,2 & & 0,4 & & & & & 0,2 & & 0,3 & & & & \\
\hline 4 & 0,3 & 0,4 & 0,3 & & 0,3 & 0,2 & & & & 0,3 & 0,3 & 0,2 & & & & 0,2 & & 0,2 & 0,3 & \\
\hline 5 & 0,4 & & 0,3 & & 0,3 & 0,2 & & & & 0,4 & 0,3 & 0,2 & & & & 0,3 & & & & \\
\hline 6 & 0,4 & 0,2 & 0,3 & 0,1 & 0,4 & 0,3 & & & & 0,1 & & 0,2 & & & & & & & 0,3 & \\
\hline 7 & 0,3 & 0,4 & & & 0,3 & & 0,3 & & & & & & & & & 0,2 & 0,3 & & & 0,1 \\
\hline 8 & 0,4 & 0,3 & & 0,2 & 0,3 & & & & & & & & 0,3 & & & 0,3 & & & 0,2 & \\
\hline 9 & 0,4 & 0,2 & & & & & & & & & & & & & & & & 0,3 & 0,4 & \\
\hline 10 & 0,4 & & & 0,3 & 0,3 & 0,3 & & 0,4 & & & & & & & & 0,1 & & & 0,3 & \\
\hline
\end{tabular}

Pada tabel bobot gejala diatas, tingkat keparahan pada gejala yang dialami pasien diindikasikan dengan nilai data mulai dari 0,1 hingga 0,4. Nilai 0 menunjukkan bahwa gejala tidak ada pada penyakit, nilai 1 dan 2 menunjukkan gejala tidak terlalu dialami atau hanya kadang kadang dialami oleh penderita, sedangkan nilai 3 dan 4 menunjukkan bahwa gejala sering dialami atau sangat pasti dialami oleh penderita. 
Procedia of Engineering and Life Science Vol. 1. No. 2 Juni 2021

Seminar Nasional \& Call Paper Fakultas Sains dan Teknologi (SENASAINS 2nd)

Universitas Muhammadiyah Sidoarjo

\section{Model Persoalan}

Pembuatan website ini menggunakan metode Naïve Bayes dalam proses diagnosis penyakit kulit. Pemilihan metode Naïve Bayes ini di karenakan pada beberapa jurnal menerangkan bahwa metode Naïve Bayes ini adalah suatu metode yang hanya membutuhkan jumlah data pelatihan (training data) yg kecil untuk menentukan estimasi parameter yg diperlukan dalam proses pengklasifikasian ${ }^{[5]}$. Proses yang digunakan meliputi proses perhitungan probabilitas dari setiap inputan data user yang selanjutnya akan terlihat perbandingan dari hasil yang telah diproses lalu hasil diagnosis akan keluar dengan nilai probabilitas terbesar. Perhitungan Naïve Bayes dilakukan dengan menggunakan rumus ${ }^{[6]}$ :

$\mathbf{P}(\mathbf{a i} \mid \mathbf{v j})=\frac{\mathbf{n c}(\text { jumlah data learning yang } \mathrm{v}=\mathrm{vj} \text { dan } \mathrm{a}=\mathrm{ai})+\mathbf{m} \text { (jumlah gejala }) \times \mathbf{p}(1 / \text { banyaknya jenis penyakit })}{\mathbf{n} \text { (jumlah data learning tiap class })+\mathbf{m} \text { (jumlah gejala) }}$

Persamaan diatas dapat diselesaikan dengan cara perhitungan pertama menentukan nilai nc untuk tiap tiap class (bobot gejala setiap penyakit) lalu menghitung nilai $\mathrm{P}(\mathrm{ai} \mid \mathrm{vj})$ dan menghitung nilai $\mathrm{P}(\mathrm{vj})$ menghtiung $\mathrm{P}(\mathrm{ai} \mid \mathrm{vj}) \mathrm{x}$ $\mathrm{P}(\mathrm{vj})$ untuk tiap tiap $\mathrm{v}$ terakhir menentukan hasil klasifikasi naïve bayes yaitu $\mathrm{v}$ atau penyakit yang memiliki hasil perkalian terbesar $^{[7]}$.

Contoh kasus :

Seorang pengguna aplikasi atau pasien bernama Tari memilih gejala gejala yang diderita berupa "kulit terasa gatal" (G1), "kulit terasa nyeri" (G2), "kulit terdapat bercak atau ruam merah" (G5) dan "kulit terasa seperti tersengat, tertusuk atau kesemutan" (G13).

Langkah pertama : Menentukan nilai nc ( jumlah data learning yang $\mathrm{v}=\mathrm{vj}$ dan $\mathrm{a}=\mathrm{ai}$ ) untuk setiap class Penyakit 1 atau $\mathrm{P} 1=$ Dermatitis Atopik

$\mathrm{n}$ (jumlah data learning tiap class) $=1$

$\mathrm{p}(1 /$ banyaknya jenis penyakit $)=1 / 10=0,1$

$\mathrm{m}($ jumlah gejala $)=20$

$\mathrm{G} 1 . \mathrm{nc}=0,4 \quad \mathrm{G} 2 \cdot \mathrm{nc}=0 \quad \mathrm{G} 5 . \mathrm{nc}=0,3 \quad \mathrm{G} 13 . \mathrm{nc}=0$

Dan seterusnya hingga penyakit kulit yang ke 10

Langkah Kedua : Menghitung nilai $P$ (ai|vj) dan menghitung nilai $P(v j)$

Penyakit 1 atau $\mathrm{P} 1=$ Dermatitis Atopik

$\mathrm{P}($ Dermatitis Atopik $)=1 / 10=0.1$

$\mathrm{P}(\mathrm{G} 1 \mid$ Dermatitis Atopik $)=\frac{0.4+20 \times 0.1}{1+20}=0.1142$

$1+20$

$\mathrm{P}(\mathrm{G} 2 \mid$ Dermatitis Atopik $)=\underline{0+20 \times 0.1}=0.0952$

$$
1+20
$$

$\mathrm{P}(\mathrm{G} 5 \mid$ Dermatitis Atopik $)=\frac{0.3+20 \times 0.1}{1+20}=0.1095$

$\mathrm{P}(\mathrm{G} 13 \mid$ Dermatitis Atopik $)=\underline{0+20 \times 0.1}=0.0952$

$$
1+20
$$

Dan seterusnya hingga penyakit kulit yang ke 10

Langkah Ketiga : Menghitung $P($ ai|vj) x P(vj) untuk tiap v

Penyakit 1 atau $\mathrm{P} 1=$ Dermatitis Atopik

P(D. Atopik) x [ P(G1| D. Atopik) x P(G2| D. Atopik) x P(G5| D. Atopik) x P(G13| D. Atopik) ]

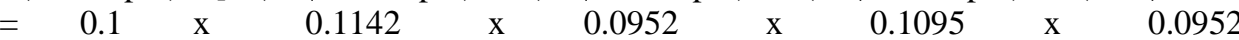

$=0.00001135$

Langkah Ke-empat : Menentukan hasil klasifikasi yaitu v yang memiliki hasil perkalian terbesar. Hasil v yang memiliki perkalian terbesar didapatkan pada Tabel 5.

Tabel 5. Tabel Nilai v Hasil Klasifikasi

\begin{tabular}{|c|l|l|}
\hline No. & \multicolumn{1}{|c|}{ Jenis Penyakit } & \multicolumn{1}{c|}{ Nilai v } \\
\hline 1 & Dermatitis Atopik & 0.00001135 \\
\hline 2 & Urtikaria & 0.00001303 \\
\hline 3 & Dermatitis Kontak (Alergi) & 0.00001305 \\
\hline
\end{tabular}


Procedia of Engineering and Life Science Vol. 1. No. 2 Juni 2021

Seminar Nasional \& Call Paper Fakultas Sains dan Teknologi (SENASAINS 2nd)

Universitas Muhammadiyah Sidoarjo

\begin{tabular}{|c|l|l|}
\hline 4 & Steven Johnsons Syndrome & 0.00001305 \\
\hline 5 & Tinea & 0.00001135 \\
\hline 6 & Kandidiasis & 0.00001303 \\
\hline 7 & Impetigo & 0.00001305 \\
\hline 8 & Herpes Zoster & $\mathbf{0 . 0 0 0 0 1 5 0 1}$ \\
\hline 9 & Veruka & 0.00000995 \\
\hline 10 & Psoriasis & 0.00001135 \\
\hline
\end{tabular}

Karena nilai $\mathrm{v}$ atau perkalian 0.00001501 paling besar, maka pasien bernama Tari berdasarkan naïve bayes classification diklasifikasikan menderita penyakit Herpes Zoster.

\section{Flowchart Aplikasi}

Untuk mempermudah merancang atau membangun sebuah website sistem pakar, maka diharuskan untuk merancang suatu diagram alur (flowchart) sehingga pembuatan sistem dapat dilakukan secara terurut ${ }^{[8]}$. Terdapat dua macam flowchart pada penelitian ini yaitu flowchart admin dan flowchart user, berikut dua flowchart :

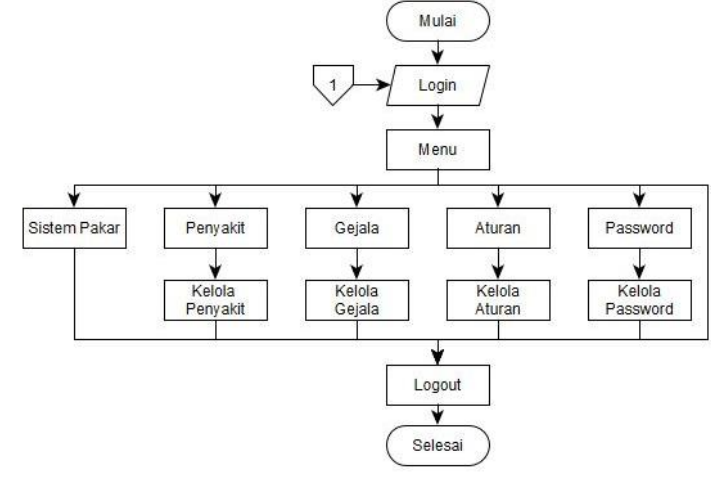

Gambar 1. Flowchart admin

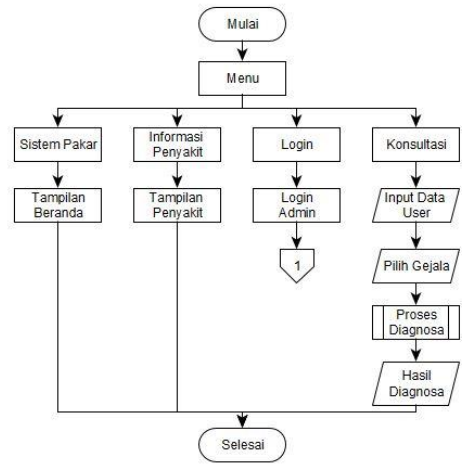

Gambar 2. Flowchart user

\section{Hasil dan Pembahasan}

\section{A. Implementasi Sistem}

Pada implementasi pengembangan antarmuka perangkat lunat pada platform website di dapatkan beberapa halaman sebagai berikut :

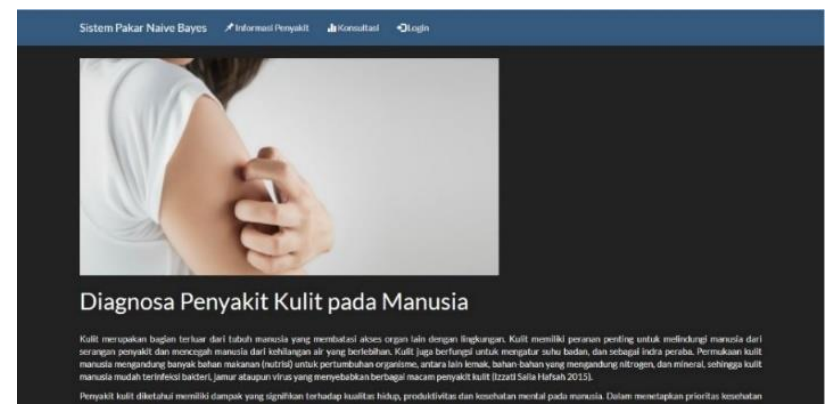

. Gambar 3. Tampilan Antar Muka Halaman Utama User

Saat seorang user membuka website sistem pakar diagnosis penyakit kulit, maka akan menampilkan halaman utama seperti diatas. Halaman beranda ini menampilkan latar belakang mengapa sistem pakar ini dibuat. 
Procedia of Engineering and Life Science Vol. 1. No. 2 Juni 2021

Seminar Nasional \& Call Paper Fakultas Sains dan Teknologi (SENASAINS 2nd)

Universitas Muhammadiyah Sidoarjo

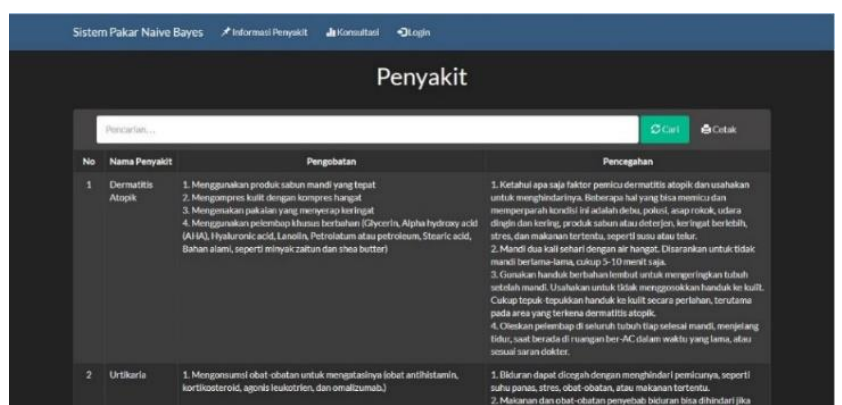

Gambar 4. Tampilan Antar Muka Informasi Penyakit

Menu website yang kedua adalah menu informasi penyakit. Menu informasi penyakit ini menampilkan tentang 10 daftar penyakit yang telah diinputkan oleh admin pada sistem beserta keterangan tentang cara cara pencegahan penyakit dan cara cara pengobatan penyakit.

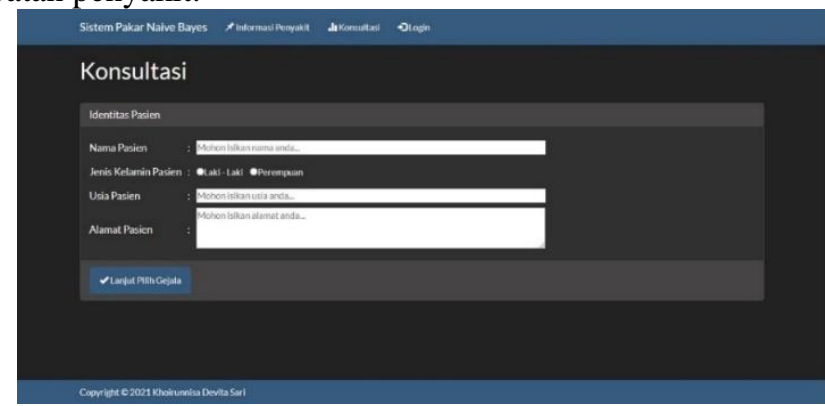

Gambar 5. Tampilan Antar Muka Konsultasi

Menu yang ketiga adalah menu konsultasi. Pada menu atau halaman konsultasi ini seorang user harus menginputkan data seperti nama, jenis kelamin, usia dan alamat user. Setelah user menginputkan data data diatas langkah selanjutnya adalah user memilih gejala gejala yang di alami oleh user dengan tampilan seperti dibawah :

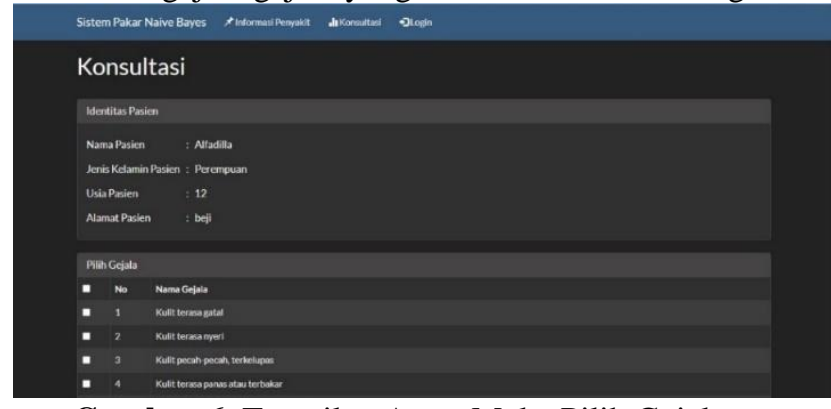

Gambar 6. Tampilan Antar Muka Pilih Gejala

Data nama, jenis kelamin, usia dan alamat yang telah di inputkan oleh user pada halaman awal konsultasi akan tampil pada halaman pilih gejala ini. Pada halaman pilih gejala ini user harus memilih gejala gejala yang sedang di alami lalu mengklik tombol submit diagnosa untuk selanjutnya akan di diagnosis oleh website sistem pakar.
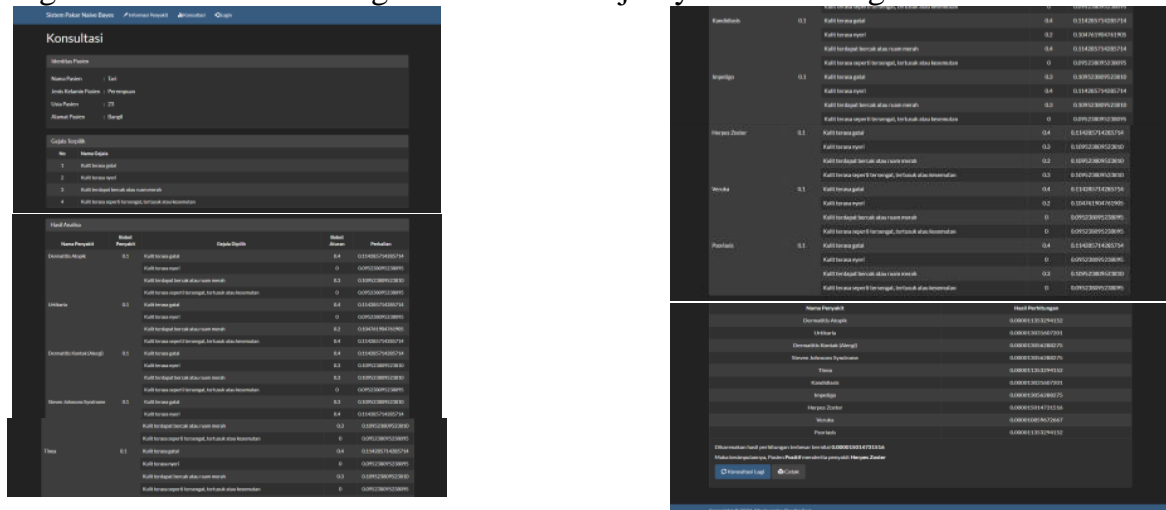

Gambar 7. Tampilan Antar Muka Hasil Konsultasi 
Procedia of Engineering and Life Science Vol. 1. No. 2 Juni 2021

Seminar Nasional \& Call Paper Fakultas Sains dan Teknologi (SENASAINS 2nd)

Universitas Muhammadiyah Sidoarjo

Setelah user atau pasien memilih gejala yang dialami lalu mengklik submit diagnosa maka website sistem pakar akan langsung menampilkan hasil diagnosis. Pada halaman ini akan menampilkan nama, usia, jenis kelamin dan alamat yang telah diinput oleh user, lalu dibawahnya ada hasil diagnosa dengan kesimpulan penyakit yang sedang di derita user.

\section{B. Hasil Pengujian}

Dilakukan dua kali pengujian pada website yaitu pengujian fungsional yang dilakukan dengan metode black box dan pengujian eksternal yang dilakukan dengan menggunakan metode UAT. Pengujian black box ini dilakukan dengan cara membagi masukan (input) ke dalam kelas kelas sehingga test case pada website dapat diperoleh ${ }^{[9]}$. Sedangkan pengujian UAT ini dilakukan dengan cara mengajukan pertanyaan pertanyaan yang berhubungan dengan sistem kepada seseorang yang bertindak sebagai pengguna ${ }^{[10]}$. Hasil dari pengujian eksternal adalah $90 \%$ responden memilih bahwa website memiliki tampilan menarik, mudah dipahami, user friendly, efektif, dan bermanfaat. Lalu dilakukan pengujian ketepatan website sistem pakar terhadap 20 responden website, maka kesimpulan yang bisa diambil berdasarkan hasil tabel 6 dibawah adalah website sistem pakar yang telah dibangun dapat memberikan hasil diagnosis berdasarkan aturan aturan yang telah diinputkan dan website dapat mendiagnosis penyakit kulit dengan baik.

Tabel 6. Tabel hasil diagnosis

\begin{tabular}{|l|l|l|l|l|}
\hline No & Nama & Nilai Naïve Bayes & Nama Penyakit & Hasil \\
\hline 1 & Liana & 0,000000018832861 & Dermatitis Kontak (Alergi) & Valid \\
\hline 2 & Putri & 0,000000001972966 & Urtikaria & Valid \\
\hline 3 & Dina Aini Bashiroh & 0,000000019688900 & Dermatitis Kontak (Alergi) & Valid \\
\hline 4 & Fareel Ramadhan & 0,000014986348281 & Veruka & Valid \\
\hline 5 & Ely Indriani & 0,000000002062647 & Dermatitis Kontak (Alergi) & Valid \\
\hline 6 & Agnas Johan Manurung & 0,000000002062647 & Dermatitis Kontak (Alergi) & Valid \\
\hline 7 & Isnaini Widya & 0,000000187939497 & Psoriasis & Valid \\
\hline 8 & Ratna Ningsih & 0,000000017263455 & Urtikaria & Valid \\
\hline 9 & Rehan & 0,000000187939497 & Psoriasis & Valid \\
\hline 10 & Nurillah Afidah & 0.000000002062647 & Tinea & Valid \\
\hline 11 & Avief Maulana M & 0,000000002156403 & Dermatitis Kontak (Alergi) & Valid \\
\hline 12 & Achmad Fahmi & 0,000000002062647 & Dermatitis Kontak (Alergi) & Valid \\
\hline 13 & Sadam & 0,000000002062647 & Dermatitis Kontak (Alergi) & Valid \\
\hline 14 & Ojan & 0,000000001804816 & Dermatitis Atopik & Valid \\
\hline 15 & Hafis Ahmad & 0,000000001719522 & Kandidiasis & Valid \\
\hline 16 & Nur Kholis Sujoko & 0,000000018793950 & Psoriasis & Valid \\
\hline 17 & Syafira & 0,000000018793950 & Psoriasis & Valid \\
\hline 18 & Astria & 0,000000001804816 & Dermatitis Atopik & Valid \\
\hline 19 & Linda & 0,000014986348281 & Veruka & Valid \\
\hline 20 & Khoirunnisa Devita Sari & 0,000000187939497 & Psoriasis & Valid \\
\hline
\end{tabular}

\section{KESIMPULAN}

Dari penelitian yang telah dilakukan oleh peneliti, dapat disimpulkan bahwa perancangan dan penbangunan website sistem pakar diagnosis penyakit kulit menggunakan naïve bayes berbasis website dapat memberikan hasil diagnose berdasarkan fakta fakta yang telah diberikan, pemilihan menggunakan metode Naïve Bayes digunakan karena bisa mendapatkan hasil yang sangat baik dan tepat, metode Naïve Bayes dipilih dalam melakukan penelitian ini dikarenakan metode ini sesuai untuk studi kasus dengan variable 20 gejala dan dapat menentukan hasil penyakit yang diderita dengan sangat baik dan tepat.

Pada website sistem pakar ini juga pastiterdapat banyak kekurangan baik dari segi User Interface, kalimat, dan lain lain. Berikut ini adalah beberapa saran dari pengguna untuk pengembang agar website dapat berjalan dengan lebih baik lagi di versi selanjutnya, yaitu website diharapkan ditambahkan dengan mode light mode, menyertakan gambar pada masing masing penyakit. Terdapat juga saran saran dari peneliti untuk kelanjutan penelitian selanjutnya, yaitu untuk penelitian selanjutnya sebaiknya dilakukan perbandingan dengan menggunakan metode lain agar bisa mendapatkan metode yang lebih baik, untuk penelitian selanjutnya diharapkan program bisa mencakup lebih banyak penyakit kulit. 


\section{UCAPAN TERIMA KASIH}

Penulisan artikel ilmiah yang berjudul Sistem Pakar Diagnosis Penyakit Kulit Manusia Menggunakan Metode Naïve Bayes Berbasis Web ini melibatkan berbagai pihak, baik secara langsung maupun secara tidak langsung. Oleh karena itu pada kesempatan ini penulis menyampaikan ucapan terima kasih kepada semua pihak yang telibat.

\section{REFERENSI}

[1] K. Kesehatan, Profil Kesehatan Indonesia Tahun 2015. 2015.

[2] Daili, Ess, Sl Menaldi, and Im Wisnu. 2005. "Penyakit Kulit Yang Umum Di Indonesia." Jakarta Pusat: Pt Medical Multimedia Indonesia Kramat ..., 66-67.

[3] Candra Dewi, Indriana, Arief Andy Soebroto, and Muhammad Tanzil Furqon. 2015. "Sistem Pakar Diagnosa Penyakit Sapi Potong Dengan Metode Naive Bayes." Journal of Enviromental Engineering and Sustainable Technology 2 (2): 72-78. https://doi.org/10.21776/ub.jeest.2015.002.02.2.

[4] Ramadhan, Kurnia, I Gede Pasek Suta Wijaya, and Moh.Ali Albar. n.d. "Sistem Pakar Diagnosa Penyakit Kulit Berbasis Website Menggunakan Metode Naive Bayes ( Web Based Expert System For Diagnostic Skin Disease Using Naive Bayes Method )."

[5] Aditya Nugroho, Praditio, Ristu Saptono, and Meiyanto Eko Sulistyo. 2016. "Perbandingan Metode Probabilistik Naive Bayesian Classifier Dan Jaringan Syaraf Tiruan Learning Vector Quantization Dalam Kasus Klasifikasi Penyakit Kandungan.” Jurnal Teknologi \& Informasi ITSmart 2 (2): 21. https://doi.org/10.20961/its.v2i2.628.

[6] Setiawan, Wahyudi, and Sofie Ratnasari. 2015. "Sistem Pakar Diagnosis Penyakit Mata Menggunakan Naïve Bayes." Conference Paper, no. November 2014: 1-6.

[7] Widiyawati, Cerly, and Mohammad Imron. 2018. "Sistem Pakar Diagnosa Penyakit Pada Kucing Menggunakan Metode Naive Bayes Classifier.” Techno.Com 17 (2): 134-44. https://doi.org/10.33633/tc.v17i2.1625.

[8] Ilyas, I. 2016. "Sistem Pakar Diagnosa Penyakit Dan Relasionalitas Obat Apotek Amor.” http://repositori.uinalauddin.ac.id/2907/.

[9] Ikhlaashi, Sofiyah, and Hanson Prihantoro Putro. 2019. "Komparasi Dua Teknik Black Box Testing: Equivalence Partitioning Dan Boundary Value Analysis." Annual Research Seminar (ARS) 20195 (1): 213-20.

[10] Munthe, Rouli, Paulus Insap Santosa, and Ridi Ferdiana. 2015. "Usulan Metode Evaluasi User Acceptance Testing (UAT) Dalam Pengembangan Perangkat Lunak." Prosiding Seminar Nasional Pendidikan Teknik Informatika, no. September: 3. http://pti.undiksha.ac.id/senapati. 